\title{
Analisa karakteristik briket campuran bahan dasar tempurung kelapa, kulit kacang, dan kulit kedelai terhadap nilai kalor menggunakan metode torefaksi microwave
}

\author{
Kuntang Winangun ${ }^{1 *}$, Muh. Malyadi ${ }^{2}$, Achmat Rifay $^{3}$ \\ 1,2,3 Prodi Teknik Mesin, Fakultas Teknik, Universitas Muhammadiyah Ponorogo \\ Jl. Budi Utomo No.10 Ponorogo \\ *Corresponding author: kuntang@umpo.ac.id
}

\begin{abstract}
Fossil fuel is a non-renewable fuel. It is necessary to find alternative energies by converting coconut shell waste, peanut shell waste, and soybean shell waste into briquettes. This study aims to utilize agricultural waste and determine the test parameters for the value of ash content, moisture content, temperature, flame duration, and calorific value of the briquette mixture of peanut shell, soybean shell, and coconut shell with variations in composition. This research was carried out by converting coconut shell, peanut shells, and soybean shells into charcoal with a carbonization process for 3 hours, the all waste charcoals were pulverized and sieved with a 60 mesh sieve, mixed with the addition of $10 \%$ tapioca flour adhesive, printed with a pressure of 250 psi. The briquettes were dried using a microwave machine with a power of 450 watts for 30 minutes. The results showed the highest value in briquette ingredient 1 with a mixture of $30 \%$ coconut shell, $50 \%$ peanut shell, and $20 \%$ soybean shell with a good moisture content value of $6.32 \%$, an ash content value of $0.084 \%$, a combustion heat value of $484.9^{\circ} \mathrm{C}$, the duration of the combustion flame was 1 hour 50 minutes 26 seconds, and the highest heating value was $7447.964 \mathrm{cal} / \mathrm{g}$. The calorific value that does not meet the standard material 2 with a composition of $30 \%$ coconut shell, $20 \%$ peanut shell and $50 \%$ soybean shell produces a heat below the SNI, namely $4649.299 \mathrm{cal} / \mathrm{g}$. For moisture and ash content in all materials meet the standards.
\end{abstract}

Keywords: Briquettes, coconut shell, peanut shell, soybean shell.

\begin{abstract}
Abstrak
Bakar fosil merupakan bahan bakar yang tidak dapat diperbarui. Perlu dicari energi aternatif dengan merubah limbah tempurung kelapa, kulit kacang, dan kulit kedelai menjadi briket. Penelitian bertujuan untuk pemanfaatan limbah pertanian dan mengetahui parameter pengujian nilai kadar abu, kadar air, temperatur, lama nyala pembakaran, dan nilai kalor dari briket campuran bahan kulit kacang, kulit kedelai, dan tempurung kelapa dengan variasi komposisi. Penelitian ini dilakukan dengan merubah limbah tempurung kelapa, kulit kacang, dan kulit kedelai menjadi arang dengan proses karbonisasi selama 3 jam, ketiga arang limbah dihaluskan dan diayak dengan ayakan 60 mesh, dicampur dengan penambahan $10 \%$ perekat tepung tapioka, dicetak dengan tekanan 250 psi. Briket dikeringkan mengunakan mesin microwave dengan daya 450 Watt selama 30 menit. Hasil penelitian menunjukkan nilai tertinggi pada briket bahan 1 dengan campuran 30\% tempurung kelapa, 50\% kulit kacang, dan $20 \%$ kulit kedelai dengan nilai kadar air yang baik sebesar 6,32\%, nilai kadar abu sebesar $0,084 \%$, nilai panas pembakaran sebesar $484,9^{\circ} \mathrm{C}$, nilai lama nyala pembakaran 1 jam 50 menit 26 detik, dan nilai kalor tertinggi sebesar 7447,964 kal/g. nilai kalor yang tidak memenuhi standar bahan 2 dengan komposisi 30\% tempurung kelapa, 20\% kulit kacang dan 50\% kulit kedelai menghasilkan kalor di bawah SNI yaitu 4649,299 kal/g. Untuk kadar air dan abu di semua bahan sudah memenuhi standar.
\end{abstract}

Kata kunci: Briket, tempurung kelapa, kulit kacang, kulit kedelai 


\section{Pendahuluan}

Energi merupakan salah satu faktor yang berdampak besar pada pertumbuhan perekonomian dan pembangunan sebuah negara, terutama di negara Indonesia. Salah satu energi yang berpengaruh besar pada kehidupan sehari-hari manusia adalah bahan bakar fosil seperti minyak bumi dan gas alam. Seiring pertambahan penduduk yang semakin meningkat di setiap tahunnya menyebabkan meningkatnya kunsumsi energi di banyak sektor seperti industri, listrik, dan transportasi. Hal ini menyebabkan semakin berkurangnya bahan bakar fosil karena bahan bakar fosil merupakan bahan bakar yang tidak dapat diperbarui. Oleh sebab itu agar masyarakat tidak tergantung pada bahan bakar fosil perlu dicari energi terbarukan.

Salah satu energi alternatif yang saat ini masih diteliti dan dikembangkan adalah bahan yang berasal dari limbah pertanian menjadi bahan bakar biomassa. Limbah pertanian merupakan material sisa di lingkup pertanian seperti kulit kacang, kulit kedelai, tempurung kelapa dan lain sebagainya.

Energi alternatif untuk mengurangi bahan bakar minyak dan gas yaitu dengan mengubah limbah pertanian menjadi bioarang karena bio arang memiliki nilai kalor yang tinggi yang melebihi kalor biomassa. Mayoritas limbah pertanian dapat dijadikan briket melalui proses pengarangan yang benar. Karakteristik setiap bahan memiliki sifat berbeda dan memiliki nilai kalor yang berbeda, bahan limbah yang memiliki kalor tinggi diantaranya kulit kacang, kulit kedelai, dan tempurung kelapa. Berdasarkan penelitian sebelumnya ketiga bahan tersebut memiliki nilai kalor yang tinggi. Penelitian tentang analisis termofisik pada briket kulit kacang dan didapat nilai kalor sebesar 4301,01- 4831,44 $\mathrm{kal} / \mathrm{g}$ pada briket kulit kacang dan memiliki nilai kandungan kimia seperti lignin 30$40 \%$, hemiselulosa $25-30 \%$, sealulos $25-$ $30 \%$, abu 5,3-7,3\%, air 4,95-7,75\%. Kulit kedelai memiliki kandungan kimia kadar air 82,45\%, kadar abu 0,51\%, lemak
$0,34 \%$, protein $1,65 \%$, serat kasar $6,18 \%$ [1], dan memiliki kalor tertinggi 5569,966 $\mathrm{kal} / \mathrm{g}$ hasil pengujian [2]. Tempurung kelapa memiliki kandungan kimia seperti lignin $29,4 \%$, nitrogen $0,1 \%$, air $8,0 \%$, abu $0,6 \%$. Tempurung kelapa memiliki nilai kalor tinggi dengan suhu pengarangan $550^{\circ} \mathrm{C}$ menghasilkan nilai kalor yang sangat tinggi sebesar $8142.685 \mathrm{kal} / \mathrm{g}$ hasil pengujian [3].

Bahan yang digunakan meliputi: limbah kulit kacang, kulit kedelai, tempurung kelapa. Limbah tersebut melimpah dan hanya dibakar begitu saja saat setelah panen. Jika dibuat bahan briket akan memiliki nilai tambah dan memanfaatkan energi. Perekat yang digunakan adalah tepung kanji sebanyak 10\% dari jumlah bahan [4].

\section{Tinjauan Pustaka}

Biobriket merupakan sebuah batangan arang dibuat dengan bahan dasar limbah pertanian dan limbah peternakan dan dicetak menggunakan alat press agar menghasilkan nilai kalor yang tinggi. Negara Asia bagian selatan masih banyak memanfaatkan biobriket contohnya negara Indonesia, Thailand, dan China [5][6].

Dua jenis briket yang dikenal yaitu :

a. Jenis Yontan atau silinder berlubang biasanya jenis ini digunakan untuk keperluan rumah tangga. Briket jenis ini berbentuk silinder dengan garis tengah $150 \mathrm{~mm}$, tinggi $142 \mathrm{~mm}$, berat $3,5 \mathrm{~kg}$, dan memiliki lubang kurang lebih sebanyak 22 lubang.

b. Jenis Mametan atau bantal/telur biasanya untuk keperluan industri dan rumah tangga. Jenis ini mempunyai lebar $32-39 \mathrm{~mm}$, panjang $46-58 \mathrm{~mm}$, dan tebal 20-24 mm.

\section{Metode Penelitian}

\section{Alat dan Bahan}

Alat dan bahan yang digunakan dalam pembuatan briket dari limbah pertanian adalah sebagai berikut: 
Tabel 1. Alat dan bahan pembuatan briket

\begin{tabular}{cc}
\hline Alat & Bahan \\
\hline -Mesin pengaduk & - Kulit kacang \\
\hline -Ayakan (60 mesh) & -Kulit kedelai \\
\hline -Mikrowave 800watt & $\begin{array}{c}\text {-Tempurung } \\
\text { kelapa }\end{array}$ \\
\hline -Cetakan briket & $\begin{array}{c}\text {-Tepung tapioka } \\
\text { (perekat) }\end{array}$ \\
\hline -Alat pres & \\
\hline -Timbangan digital & \\
\hline
\end{tabular}

\section{Pencampuran}

Bahan yang digunakan meliputi: limbah kulit kacang, kulit kedelai, tempurung kelapa. Limbah tersebut melimpah dan hanya dibakar begitu saja saat setelah panen. Jika dibuat bahan briket akan memiliki nilai tambah dan memanfaatkan energi [7]. Bahan dalam satu sampel sebanyak 100 gram. Adapun campuran yang digunakan sebagai berikut:

Tabel 2. Campuran bahan

\begin{tabular}{ccccc}
\hline No & $\begin{array}{c}\text { Perekat } \\
(\%)\end{array}$ & $\begin{array}{c}\text { Tempurung } \\
\text { kelapa } \\
\text { (gram) }\end{array}$ & $\begin{array}{c}\text { Kulit } \\
\text { kacang } \\
\text { (gram) }\end{array}$ & $\begin{array}{c}\text { Kulit } \\
\text { kedelai } \\
\text { (gram) }\end{array}$ \\
\hline 1 & 10 & 30 & 50 & 20 \\
2 & 10 & 50 & 30 & 20 \\
3 & 10 & 30 & 20 & 50 \\
\hline
\end{tabular}

\section{Hasil dan Pembahasan}

Hasil pengujian briket pada parameter nilai kalor, berat abu, kadar air ditunjukkan pada Tabel 3.

Tabel 3. Hasil pengujian briket

\begin{tabular}{ccccc}
\hline Sampel & $\begin{array}{l}\text { Berat } \\
\text { awal } \\
\text { (gram) }\end{array}$ & $\begin{array}{l}\text { Nilai } \\
\text { kalor } \\
\text { (kal/gr) }\end{array}$ & $\begin{array}{l}\text { Berat } \\
\text { abu } \\
\text { (gram) }\end{array}$ & $\begin{array}{l}\text { Kadar } \\
\text { air }(\%)\end{array}$ \\
\hline 1 & 0.5 & 7448 & 0.042 & 6.32 \\
2 & 0.5 & 4649 & 0.022 & 5.44 \\
3 & 0.5 & 5523 & 0.029 & 6.10 \\
\hline
\end{tabular}

Keterangan sampel:

1. $30 \%$ tempurung kelapa, $\% 0 \%$ Kulit kacang, 20\% kulit kedelai

2. $30 \%$ tempurung kelapa, $20 \%$ kulit kacang, 50\% kulit kedelai

3. $50 \%$ tempurung kelapa, $30 \%$ kulit kacang, 20\% kulit kedelai

\section{Nilai kalor}

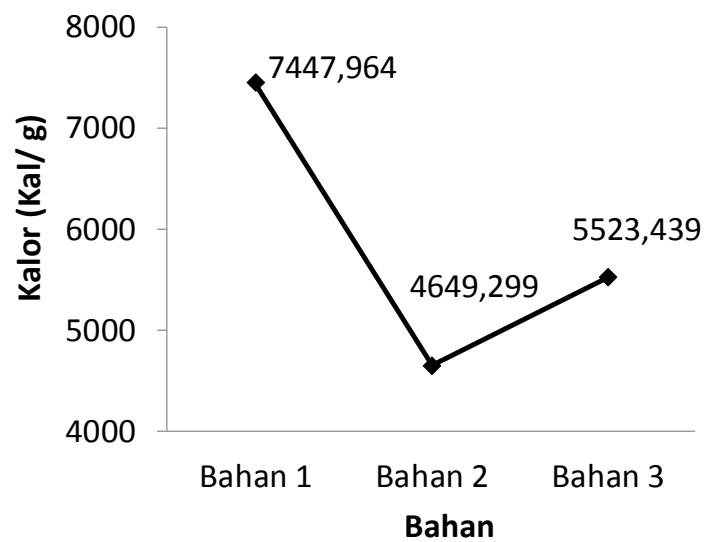

Gambar 1. Nilai kalor dari masing-masing bahan

Dari gambar 1 dapat diketahui bahwa nilai kalor tertinggi pada bahan 1 dengan komposisi $30 \%$ tempurung kelapa, 50\% kulit kacang, 20\% kulit kedelai dengan nilai kalor rata-rata $7448 \mathrm{kal} / \mathrm{g}$. Sedangkan nilai terendah pada bahan 2 dengan komposisi $30 \%$ tempurung kelapa, 20\% kulit kacang, $50 \%$ kulit kedelai dengan nilai kalor ratarata 4649,3 kal $/ \mathrm{g}$. Sedangkan standar nilai kalor di Indonesia adalah $5000 \mathrm{kal} / \mathrm{g}$. Dapat dilihat dari gambar di atas bahwa pada bahan 2 belum memenenuhi standar nilai kalor, dan bahan 1 dan bahan 3 sudah memenuhi standar nilai kalor di Indonesia. Nilai kalor juga dipengaruhi oleh kadar air, kadar abu, dan nilai tekan. Dalam pengujian ini briket yang memiliki nilai kalor adalah bahan 1 dengan bahan paling dominan adalah kulit kacang sebesar 50\% ini disebabkan bahwa arang kulit kacang sudah menghasilkan nilai kalor yang tinggi, seperti penelitian sebelumnya [8][9], pada penelitian tersebut briket kulit kacang dengan berat briket 75 gram dan awal karbonisasi bahan $250^{\circ} \mathrm{C}$ menghasilkan kalor sebesar $6.500 \mathrm{kal} / \mathrm{gr}$. Selain itu seperti yang dilakukan peneliti lain [1], rasio pencampuran yang menghasilkan nilai pembakaran paling optimal adalah $500^{\circ} \mathrm{C}$ (70\% SK : $10 \%$ KK) senilai 5670,5381 $\mathrm{kal} / \mathrm{g}$. Dilihat dari penelitian sebelumnya dengan pencampuran kulit kacang 10\% mampu menghasilkan nilai kalor yang memenuhi standar nilai kalor Indonesia. Selain itu bahan 1 memiliki kadar air yang tinggi sebesar $6,32 \%$ ini sudah memenuhi 
standar nilai kadar air Indonesia sebesar 8\%, pada penelitian ini juga memiliki nilai kalor terbaik yakni karena kulit kacang dan tempurung kelapa adalah bahan dengan kalor tinggi sehingga menghasilkan nilai kalor yang tinggi. Jadi kulit kacang sangat baik untuk bahan briket.

\section{Berat abu}

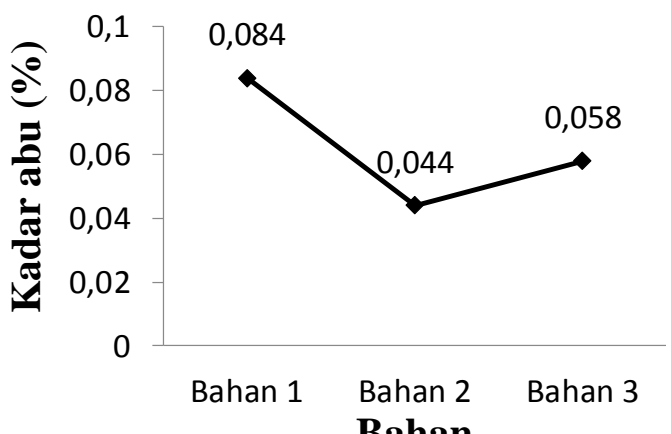

Gambar 2. Berat abu dari masing-masing bahan

Gambar 2 dapat diketahui bahwa nilai kadar abu tertinggi pada bahan 1 dengan komposisi 30\% tempurung kelapa, $50 \%$ kulit kacang, dan 20\% kulit kedelai dengan nilai kalor $0,084 \%$. Sedangkan nilai kadar abu terendah pada bahan 2 dengan komposisi 30\% tempurung kelapa, 20\% kulit kacang, dan 50\% kulit kedelai menghasilkan milai kadar abu sebesar $0,044 \%$. Standar indonesia nilai kadar abu adalah $8 \%$. Dapat dipastikan nilai kadar abu dari semua bahan sudah memenuhi standar nilai kadar abu di Indonesia. Nilai kadar abu yang paling bagus adalah bahan 2 dengan komposisi $30 \%$ tempurung kelapa, $20 \%$ kulit kacang, dan 50\% kulit kedelai menghasilkan nilai kadar abu 0,044\%. Dilihat dari penelitian ini kadar abu yang paling baik adalah bahan 2 dengan campuran paling banyak arang kulit kedelai dengan campuran 50\% arang kulit kedelai, hal ini disebabkan karena proses pengarangan limbah kulit kedelai lebih cepat dan lebih rendah kadar airnya [2][10]. Dalam pembakaran briket pasti meningalkan sisa yaitu abu. Salah satu dari penyusun abu adalah silika, silika pada proses pembakaran tidak baik pada nilai kalor yang dihasilkan oleh briket [1113]. Pengoptimalan karbonisasi pada bahan sangatlah penting, karbonisasi yang maksimal mempengaruhi nilai kadar abu pada briket semakin rendah. Semakin rendah kadar abu maka semakin baik panas yang dihasilkan briket.

\section{Kadar air}

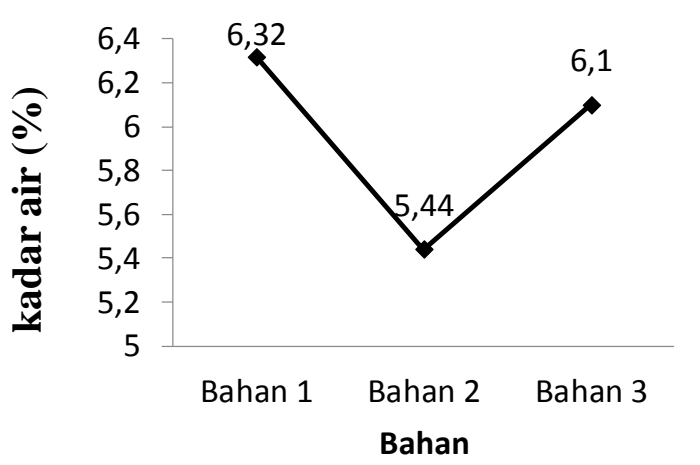

Gambar 3. Kadar air dari masing-masing bahan

Dari gambar 3 dapat diketahui nilai kadar air tertinggi pada bahan ke 1 dengan komposisi 30\% tempurung kelapa, 50\% kulit kacang, dan $20 \%$ kulit kedelai dengan nilai kadar air $6.32 \%$ dan nilai terendah pada bahan ke 2 dengan 30\% tempurung kelapa, 20\% kulit kacang, 50\% kulit kedelai dengan nilai kadar air $5.44 \%$. Nilai kadar air yang paling bagus adalah bahan ke 2 dengan komposisi 30\% tempurung kelapa, 20\% kulit kacang, dan 50\% kulit kedelai dengan nilai kadar air $5.44 \%$, dalam penelitian ini yang paling dominan adalah kulit kedelai dengan besar campuran $50 \%$ arang kulit kedelai mengasilkan kadar air rendah dengan besar $5.44 \%$ ini menyatakan bahwa arang kulit kedelai memiliki kadar air rendah. Yang mempengaruhi kandungan kadar air dari arang kulit kedelai yaitu kandungan kimianya seperti lignin, hemiselulosa, dan selulosa yang mempengaruhi kadar air pada arang kulit kedelai sehinga memiliki kadar air yang rendah [2]. Selain itu, kadar air akan mempengaruhi mudah tidaknya briket tersebut untuk dibakar [12][14].

\section{Kesimpulan}

Hasil uji briket menujukkan bahwa nilai kadar air yang baik pada bahan 2 dengan komposisi 30\% tempurung kelapa, $20 \%$ kulit kacang, dan 50\% kulit kedelai 
menghasilkan nilai kadar air rata-rata $5,44 \%$. Nilai kadar abu yang baik terdapat pada bahan 2 dengan komposisi $30 \%$ tempurung kelapa, 20\% kulit kacang dan $50 \%$ kulit kedelai dengan nilai kadar abu $0,044 \%$. Nilai panas pembakaran yang baik pada bahan 1 dengan komposisi 30\% tempurung kelapa, 50\% kulit kacang, dan $20 \%$ kulit kedelai menghasilkan nilai panas pembakaran sebesar $484,9^{\circ} \mathrm{C}$. Nilai uji lama nyala pembakaran yang baik pada bahan 1 dengan komposisi 30\% tempurung kelapa, $50 \%$ kulit kacang, dan $20 \%$ kulit kedelai menghasilkan waktu lama nyala pembakaran 1 jam 50 menit 26 detik. Nilai kalor yang baik terdapat pada bahan 1 dengan komposisi 30\% tempurung kelapa, $50 \%$ kulit kacang, dan 20\% kulit kedelai menghasilkan nilai kalor sebesar 7447.964 $\mathrm{kal} / \mathrm{g}$.

Hasil uji menunjukkan briket yang paling baik adalah briket bahan 1 dengan campuran $30 \%$ tempurung kelapa, 50\% kulit kacang, dan $20 \%$ kulit kedelai dengan nilai kadar air yang baik sebesar $6,32 \%$, nilai kadar abu sebesar $0,084 \%$, nilai panas pembakaran sebesar $484,9^{\circ} \mathrm{C}$, nilai lama nyala pembakaran 1 jam 50 menit 26 detik, dan nilai kalor tertinggi sebesar 7447,964 $\mathrm{kal} / \mathrm{g}$.

\section{Ucapan terimakasih}

Penelitian ini tidak dapat berjalan dengan lancar tanpa ada dukungan dari berbagai pihak, di kesempatan ini peneliti mengucapkan terimakasih kepada:

1. Kementerian Riset, Teknologi, dan Perguruan Tinggi yang telah mendanai penuh penelitian ini.

2. Universitas Muhammadiyah Ponorogo yang telah memfasilitasi peneliti untuk mengikuti hibah bersaing Kemenristekdikti.

\section{Referensi}

[1] Setiawan, 2012. Pengaruh Komposisi Pembuatan Biobriket dari Campuran Kulit Kacang dan Serbuk Gergaji Terhadap Nilai
Pembakaran. Jurnal Teknik Kimia, 18(2), 9-16.

[2] Fauzie D. A. 2019. Pengaruh tekanan terhadap nilai kalor pada briket berbahan kulit kedelai. Buku, $1-64$.

[3] M. Triono, 2011. Analisa Karakteristik Briket Berbahan Dasar Tempurung Kelapa Dan Perekat Tepung Tapioka. Jurnal Teknik Kimia, 8(2), 60-63

[4] Ahmad Zaenul Amin, 2017. Pengaruh Variasi Jumlah Perekat Tepung Tapioka Terhadap Karakteristik Briket Arang Tempurung Kelapa. Pengaruh Variasi Jumlah Perekat Tepung Tapioka Terhadap Karakteristik Briket Arang TempurungKelapa, 15(2), 111-118. https://doi.org/10.15294/sainteknol. v15i2.11693

[5] Jain Varun, RC. Chippa Pbl. Chaurasia, Harshal Grupta dan Sarvesh Kumar Singh A, 2014. Penyelidikan eksperimental komporatif tentang sifat fisik dan kimiawi serbuk gergaji, Jurnal Internasional Teknik dan Teknologi.

[6] Muhammad Asrianto tahir. 2019. Pengaruh Variasi Komposisi Dan Ukuran Partikel Terhadap Karakteristik Briket Kombinasi Arang Tempurung Kelapa Dengan Arang Bambu. Jurnal Sain Dan Teknologi, 4(1), 75-84. https://doi.org/.1037//00332909.I26.1.78

[7] Arake, S. R. 2017. Uji Kalor Briket Limbah Tongkol Jagung dan Sekam Padi dengan Proses Karbonisasi.

[8] Wahyusi, K. N, 2012. Briket Arang Kulit Kacang Tanah Dengan Proses Karbonisasi. Jurnal Teknik Kimia, 6(2), 70-73.

[9] Kuntang Winangun, Ghulam Asrofi Buntoro, Muh. Malyadi, Fauzan Masykur, Rendy Cahyono. 2019. Analysis of Temperature Distribution and Reactor Material in 
Microwave. International Journal of Latest Engineering Research and Applications (IJLERA) ISSN: 24557137. Vol. 4 no. 11.

[10] Kuntang Winangun, Fauzan Maskur, M. Malyadi, Rendy Cahyono. 2020. Karakteristik briket kulit kacang tanah dan sekam padi menggunakan metode torefaksi pada oven microwave.

DOI: https://doi.org/10.21070/r.e.m. v4i2

[11] Gandhi. (2010). Pengaruh Variasi Jumlah Campuran Perekat Terhadap Karakteristik Arang Briket Batang Jagung. Profesional: Jurnal Ilmiah Populer Dan Teknologi Terapan, 8(1), 1-12.

[12] Sulistyaningkarti, L. 2017. Making Charcoal Briquettes from Corncobs Organic Waste Using Variation of Type and Percentage of Adhesives. JKPK (Jurnal Kimia Dan Pendidikan Kimia), 2(1), 43. https://doi.org/10.20961/jkpk.v2i1.8 518

[13] Rio Handoko, 2019. Analisa Kalor Bakar Briket Berbahan Arang Kayu Jati, Kayu Asam, Kayu Johar, Tempurung Kelapa Dan Campuran. Ilmiah, 0985(10), 481124

[14] M. Malyadi, Kuntang Winangun, Faris Tamam Kumbayani, Fauzan Maskur, Ghulam Asrofi Buntoro. 2020. Method of Drying Mixed Briquettes (Cassava Skin, Corn Weevil, Rice Straw) Using Microwave. International Journal of Latest Engineering Research and Applications (IJLERA) ISSN: 24557137. Vol 5 no.2. 